\title{
"Challenges of improving effectiveness and efficiency of the higher educational system in developing countries"
}

\begin{tabular}{|c|c|}
\hline \multirow{7}{*}{ AUTHORS } & Saheer Al-Jaghoub id https://orcid.org/0000-0001-6449-0502 \\
\hline & Ahmad Samed Al-Adwan iD https://orcid.org/0000-0001-5688-1503 \\
\hline & R http://www.researcherid.com/rid/E-3546-2019 \\
\hline & Hussein Al-Yaseen (D https://orcid.org/0000-0003-0876-5975 \\
\hline & R http://www.researcherid.com/rid/C-1187-2016 \\
\hline & Anas Al-Soud (D https://orcid.org/0000-0002-1410-8843 \\
\hline & Ahmad Areiqat iD https://orcid.org/0000-0003-0379-7409 \\
\hline ARTICLE INFO & $\begin{array}{l}\text { Saheer Al-Jaghoub, Ahmad Samed Al-Adwan, Hussein Al-Yaseen, Anas Al- } \\
\text { Soud and Ahmad Areiqat (2019). Challenges of improving effectiveness and } \\
\text { efficiency of the higher educational system in developing countries. Problems } \\
\text { and Perspectives in Management, 17(1), 19-31. doi:10.21511/ppm.17(1).2019.03 }\end{array}$ \\
\hline DOI & http://dx.doi.org/10.21511/ppm.17(1).2019.03 \\
\hline RELEASED ON & Wednesday, 06 February 2019 \\
\hline RECEIVED ON & Thursday, 18 October 2018 \\
\hline \multirow[t]{2}{*}{ ACCEPTED ON } & Wednesday, 23 January 2019 \\
\hline & $(\mathrm{cc}) \overline{\mathrm{EY}}$ \\
\hline LICENSE & $\begin{array}{l}\text { This work is licensed under a Creative Commons Attribution } 4.0 \text { International } \\
\text { License }\end{array}$ \\
\hline JOURNAL & "Problems and Perspectives in Management" \\
\hline ISSN PRINT & $1727-7051$ \\
\hline ISSN ONLINE & $1810-5467$ \\
\hline PUBLISHER & LLC “Consulting Publishing Company "Business Perspectives” \\
\hline FOUNDER & LLC “Consulting Publishing Company "Business Perspectives" \\
\hline
\end{tabular}

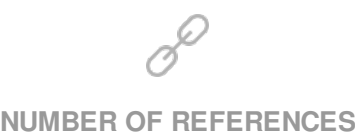

43

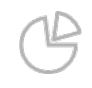

NUMBER OF FIGURES

3

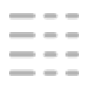

NUMBER OF TABLES

1

(C) The author(s) 2023. This publication is an open access article. 


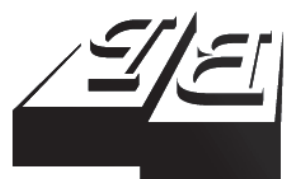

BUSINESS PERSPECTIVES

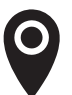

LLC "CPC "Business Perspectives" Hryhorii Skovoroda lane, 10, Sumy, 40022, Ukraine

www.businessperspectives.org

Received on: $18^{\text {th }}$ of October, 2018 Accepted on: 23 ${ }^{\text {rd }}$ of January, 2019

(c) Saheer Al-Jaghoub, Ahmad AlAdwan, Hussein Al-Yaseen, Anas Al-Soud, Ahmad Areiqat, 2019

Saheer Al-Jaghoub, Associate Professor, Faculty of Administrative and Financial Sciences, Petra University, Amman, Jordan.

Ahmad Al-Adwan, Associate Professor, Business School, AlAhliyya Amman University, Amman, Jordan.

Hussein Al-Yaseen, Professor, Business School, Al-Ahliyya Amman University, Amman, Jordan.

Anas Al-Soud, Associate Professor, Business School, Al-Ahliyya Amman University, Amman, Jordan.

Ahmad Areiqat, Associate Professor, Business School, Al-Ahliyya Amman University, Amman, Jordan.

\section{(ㄷ)(ㄱ)}

This is an Open Access article, distributed under the terms of the Creative Commons Attribution 4.0 International license, which permits unrestricted re-use, distribution, and reproduction in any medium, provided the original work is properly cited.
Saheer Al-Jaghoub (Jordan), Ahmad Al-Adwan (Jordan), Hussein Al-Yaseen (Jordan), Anas Al-Soud (Jordan), Ahmad Areiqat (Jordan)

\section{CHALLENGES OF IMPROVING} EFFECTIVENESS AND EFFICIENCY OF THE HIGHER EDUCATIONAL SYSTEM IN DEVELOPING COUNTRIES

\begin{abstract}
Due to the country's lack of natural resources and its dependence on human resources, Jordanian universities have started to implement quality assurance system aiming to improve effectiveness and efficiency of the higher educational system. This paper presents the results of a research that aims to identify the main issues and challenges facing these universities in implementing quality assurance system. Data for this research were collected using a survey mailed to all public and private universities to investigate the main issues affecting the implementation of quality assurance system in Jordanian universities.

The results of this research showed that the most important challenges faced by Jordanian universities are: human and lack of awareness, resistance to change and cultural among others. The research findings hoped to be useful for both universities and policy makers in the government in order to realize the full benefits of implementing quality assurance system. Hence, this and other research on implementing quality assurance in higher educational institutions might be of assistance.
\end{abstract}

Keywords

accreditation, quality assurance, challenges, higher education, developing countries, Jordan

\section{JEL Classification I21, I23, C83, D83}

\section{INTRODUCTION}

Higher education is the degrees that are acquired beyond the secondary level of school and provided by specialized college or university. Higher education has many purposes such as career preparation, gaining desired skills, training and knowledge (Bongaarts et al., 2017; Moreira et al., 2017). Higher education sector in developing countries in general and in the Middle East in particular plays an important role in human and society development (Lipset, 2018).

Accreditation and quality assurance in higher educational institution are considered as one of the most important factors in the enhancement of educational system (students, academic staff, infrastructure, programs, methods, etc.). Accreditation can be defined as the process in which educational institutions and programs are evaluated to determine if the required standards are met (Gaston, 2013; Espinoza \& Eduardo González, 2013; Blanco-Ramírez \& Berger, 2014; Kwiek, 2014; Hou et al., 2015; Khouja et al., 2018). In Middle East countries, the process of educational accreditation for higher education is conducted either by a government organization, such as Ministry of Higher Education (MoHE), or independent agencies as shown in Table 1. 
Table 1. Ministries of higher education and accreditation agencies

\begin{tabular}{|c|c|c|}
\hline Country & Ministry & Accreditation agency/entity \\
\hline $\begin{array}{l}\text { United Arab Emirates: } \\
\text { www.moe.gov.ae/En/ }\end{array}$ & $\begin{array}{l}\text { Ministry of Higher Education and Scientific } \\
\text { Research }\end{array}$ & $\begin{array}{l}\text { The Commission for Academic } \\
\text { Accreditation (CAA) }\end{array}$ \\
\hline $\begin{array}{l}\text { Kuwait: } \\
\text { https://www.mohe.edu.kw/en/ }\end{array}$ & Ministry of Higher Education & $\begin{array}{l}\text { Council for Higher Education } \\
\text { Accreditation (CHEA) }\end{array}$ \\
\hline $\begin{array}{l}\text { Kingdom of Saudi Arabia: } \\
\text { https://www.moe.gov.sa/en/ }\end{array}$ & $\begin{array}{l}\text { Ministry of Higher Education include the } \\
\text { higher education council }\end{array}$ & $\begin{array}{l}\text { National Commission for Academic } \\
\text { Accreditation and Assessment (NCAAA) }\end{array}$ \\
\hline $\begin{array}{l}\text { Jordan: } \\
\text { www.mohe.gov.jo/en/ }\end{array}$ & $\begin{array}{l}\text { Ministry of Higher Education and Scientific } \\
\text { Research }\end{array}$ & $\begin{array}{l}\text { Higher Education Accreditation } \\
\text { Commission (HEAC) }\end{array}$ \\
\hline $\begin{array}{l}\text { Qatar: } \\
\text { www.edu.gov.qa/en/ }\end{array}$ & $\begin{array}{l}\text { Ministry of Education and Higher } \\
\text { Education }\end{array}$ & Council for Higher Education (CHE) \\
\hline $\begin{array}{l}\text { Libya: } \\
\text { www.libyaobserver.ly/ } \\
\text { education-ministry }\end{array}$ & $\begin{array}{l}\text { General Peoples' Committee for Education } \\
\text { \& Scientific Research (GPCE\&SR) }\end{array}$ & CQAAE\&TI \\
\hline $\begin{array}{l}\text { Sultanate of Oman: } \\
\text { https://mohe.gov.om/?\&culture =en }\end{array}$ & Ministry of Higher Education & $\begin{array}{l}\text { Oman Academic Accreditation Authority } \\
\text { (OAAA) }\end{array}$ \\
\hline $\begin{array}{l}\text { Kingdom of Bahrain: } \\
\text { www.moe.gov.bh/?lan=en }\end{array}$ & $\begin{array}{l}\text { Ministry of Education (Higher Education } \\
\text { Council) }\end{array}$ & $\begin{array}{l}\text { Quality Assurance Authority for } \\
\text { Education \& Training (QAAE\&T) }\end{array}$ \\
\hline $\begin{array}{l}\text { Sudan: } \\
\text { www.mohe.gov.sd/index.php/en }\end{array}$ & $\begin{array}{l}\text { Ministry of Higher Education and Scientific } \\
\text { Research }\end{array}$ & $\begin{array}{l}\text { Evaluation and Accreditation Commission } \\
\text { (EVAC) }\end{array}$ \\
\hline $\begin{array}{l}\text { Egypt: } \\
\text { www.mohe-casm.edu.eg/En }\end{array}$ & $\begin{array}{l}\text { Ministry of Higher Education and Scientific } \\
\text { Research }\end{array}$ & $\begin{array}{l}\text { National Authority for Quality Assurance } \\
\& \text { Accreditation for Education (NAQAAE) }\end{array}$ \\
\hline $\begin{array}{l}\text { Tunisia: } \\
\text { www.mesrst.tn/anglais/index.htm }\end{array}$ & $\begin{array}{l}\text { Ministry of Higher Education and Scientific } \\
\text { Research }\end{array}$ & $\begin{array}{l}\text { Council for Higher Education } \\
\text { Accreditation (CHEA) }\end{array}$ \\
\hline Yemen: www.yemen.gov.ye & $\begin{array}{l}\text { Ministry of Higher Education and Scientific } \\
\text { Research }\end{array}$ & $\begin{array}{l}\text { Higher Council of Higher } \\
\text { Education Quality Assurance (HCHEQA) }\end{array}$ \\
\hline Palestine: www.moehe.gov.ps/ & $\begin{array}{l}\text { Ministry of Education and Higher } \\
\text { Education }\end{array}$ & $\begin{array}{l}\text { Accreditation and Quality Assurance } \\
\text { Commission (AQAC) }\end{array}$ \\
\hline
\end{tabular}

The research presented in this paper aims to answer these research questions within the context of higher educational institutions in Jordan. This paper is structured as follows: the introduction; literature review with a brief presentation of the education system; quality assurance process and accreditation; and quality assurance system implementation in Jordan. In section 2, research approach and method used were presented. In section 3, discussion about the main findings and finally conclusions are presented.

\section{LITERATURE REVIEW}

Before proceeding on to discuss accreditation and quality assurance in Jordan, it may be useful to briefly present the country's higher education system.

\subsection{Educational system in Jordan}

For Jordan in particular, education has played an important role in the development of Jordanian human capital, Jordan has invested more than 13\% of public expenditure in basic and secondary education, enrollment rate for basic education reached $90 \%$ and $70 \%$ for secondary education, Jordan has proved an impressive record of educational development. Educational reforms in Jordan have been started in the early 1990s, and the process reform was accelerated under His Majesty King Abdullah II in early 2001 by establishing many educational initiatives (Al-Adwan et al., 2018) in order to monitor and improve educational quality (Al-Jaghoub et al., 2010; Al-Soud et al., 2014; Al-Yaseen et al., 2015; MoHESR, 2018).

The educational system in Jordan (as shown in Figure 1) consists of two years of optional preschool education (mainly provided by private schools), ten years of compulsory basic education (provided by both private and public schools), two years of optional (comprehensive or applied) secondary education (provided by both private/public schools), then the student can attend a General Certificate of Secondary Education Exam called Tawjihi in public schools or the IGCSE, SAT and IB, certificates in most private schools (Al-Hassan, 2018). The students who passed the exam after completing the school with the required average in Tawjihi or in other certificates can apply for the universities (public/private) or can apply to com- 


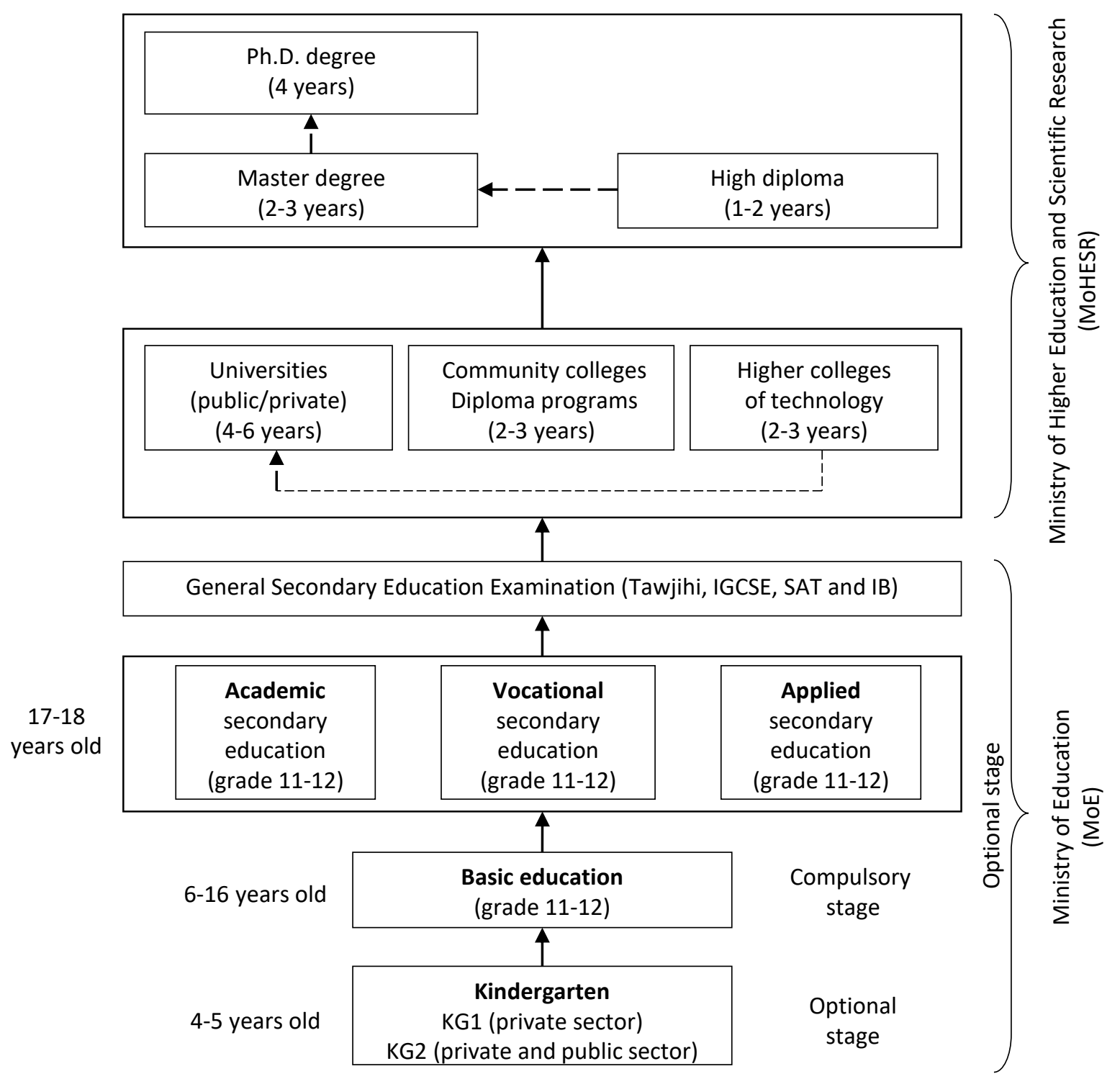

Figure 1. Educational system in Jordan

munity colleges. In such cases, after completing the community college degree, some students can continue their studies at the universities. After completing the undergraduate program, students can apply to the Master programs and after completing they can attend the available $\mathrm{PhD}$ program (mainly in some public universities, such as Jordan university) (MoE, 2018).

Higher education or post-secondary education in Jordan was unavailable until 1951 where secondary school graduates were going outside Jordan for studying. Higher education in Jordan is provided at two levels: level 1 - non-university level stud- ies (higher colleges of technology and community colleges (diploma programs) and level 2 - university level studies (Bachelor, High-diploma, Master and Doctorate Ph.D.).

Non-university level studies last for two years and in some cases for three years. This type of studies is open to holders of all types of general education certificates. There are two types of non-university level studies: higher colleges of technology and community colleges (diploma programs), non-university level studies are provided and owned either by public or private community colleges, all public community colleges are under the supervision 
of Al-Balqa Applied University. At the end of the diploma programs, students sit for a comprehensive exam called (Al-Shamel), and students who pass this exam are awarded the Associate degree (Diploma) (Kanaan, 2018).

There are 4 types of the university level studies: Bachelor's degree - normally takes 4-6 years based on the field of study (it takes 4 years in the case of business, administration, arts, mathematics, physics, chemistry; 5 years in the case of pharmacy, dentistry, architecture, engineering and veterinary medicine; 6 years in the case of surgery or medicine); High-diploma degree: one-year postgraduates programs for the Bachelor's degree holders, offered by some universities; Master's degree: normally lasts one and a half to two years programs for Bachelor's degree holders or oneyear for high-diploma degree holders; Doctorate (Ph.D.) degree: usually lasts for three to four years programmes for the Master's degree holders after submission of a dissertation. University level studies are provided and owned either by public or private universities (Al-Widyan \& Qdais, 2018).

University level studies in Jordan is the responsibility of the Ministry of Higher Education and Scientific Research (MoHESR). MoHESR includes two councils: Higher Education Council (HEC) and Accreditation Council (AC). Jordan has both private and public universities, many of which are supported by the government of Jordan. Jordan has a fairly large number of universities for its size, there are 19 private universities and 10 public universities. In addition, there are 50 community colleges in Jordan. As for university education, it started by the establishment of public university the University of Jordan in 1962, followed by the establishment of the first private university Al-Ahliyya Amman University in 1989.

Jordan has seen an increased demand for higher education where the number of enrolled students in both private and public universities has increased from 77,000 students in 2000 and 218,000 students in 2011 to reach 240,000 students in 2014 (MoHESR, 2018).

His Majesty King Abdullah II has paid special attention to the higher education sector as he directed his government to shed more light on higher education and its development. Thus, during his Majesty's reign, many private and public universities were established, the number of public universities has reached 10 universities, besides 19 private universities and 51 community colleges (AlYaseen, 2012; Al-Yaseen \& Al-Jaghoub, 2012).

\subsection{Quality assurance process and accreditation}

Quality assurance in higher education can be defined as the process of assessing and monitoring programs, guaranteeing and maintaining, then improving quality of higher educational institutions (Houston \& Paewai; 2013; Al-Yaseen et al., 2013; Hou, 2014; Stimac \& Katic, 2015). In some countries, Ministry of Higher Education is responsible for quality assurance process, however, in other countries, quality assurance process is performed by independent agencies (Damian et al., 2015; Dill, 2015; Dunn et al., 2017). A number of developing countries have started implementing quality assurance system in their universities (Hou, 2014; Laguador et al., 2014; Dotong \& Laguador, 2015; Navaneedhan \& Kamalanabhan, 2015), but the level of implementation varies among countries due to the differences in a number of issues such as awareness, acceptability, change and culture (Ebisine, 2014; Altbach, 2015; Kanaan, 2018).

With the establishment of the first private university in Jordan in 1989 (Al-Ahliyya Amman University), the Accreditation Council (AC) was established in Jordan in 1990 and evolved as a result of a rapid expansion in the higher education private and public sector. In 1990, the main role of the Accreditation Council was to formulate criteria for public and private universities, to establish quality assurance measures for public and private universities, and to establish monitoring system to ensure that universities are compliant with the criteria (MoHESR, 2018).

In 2007, Accreditation Council has been replaced by the Higher Education Accreditation Commission (HEAC), and it granted administrative and financial independence, its main role was to monitor the development and maintenance of quality in Jordanian universities, and to implement the National Center for Testing. HEAC vi- 


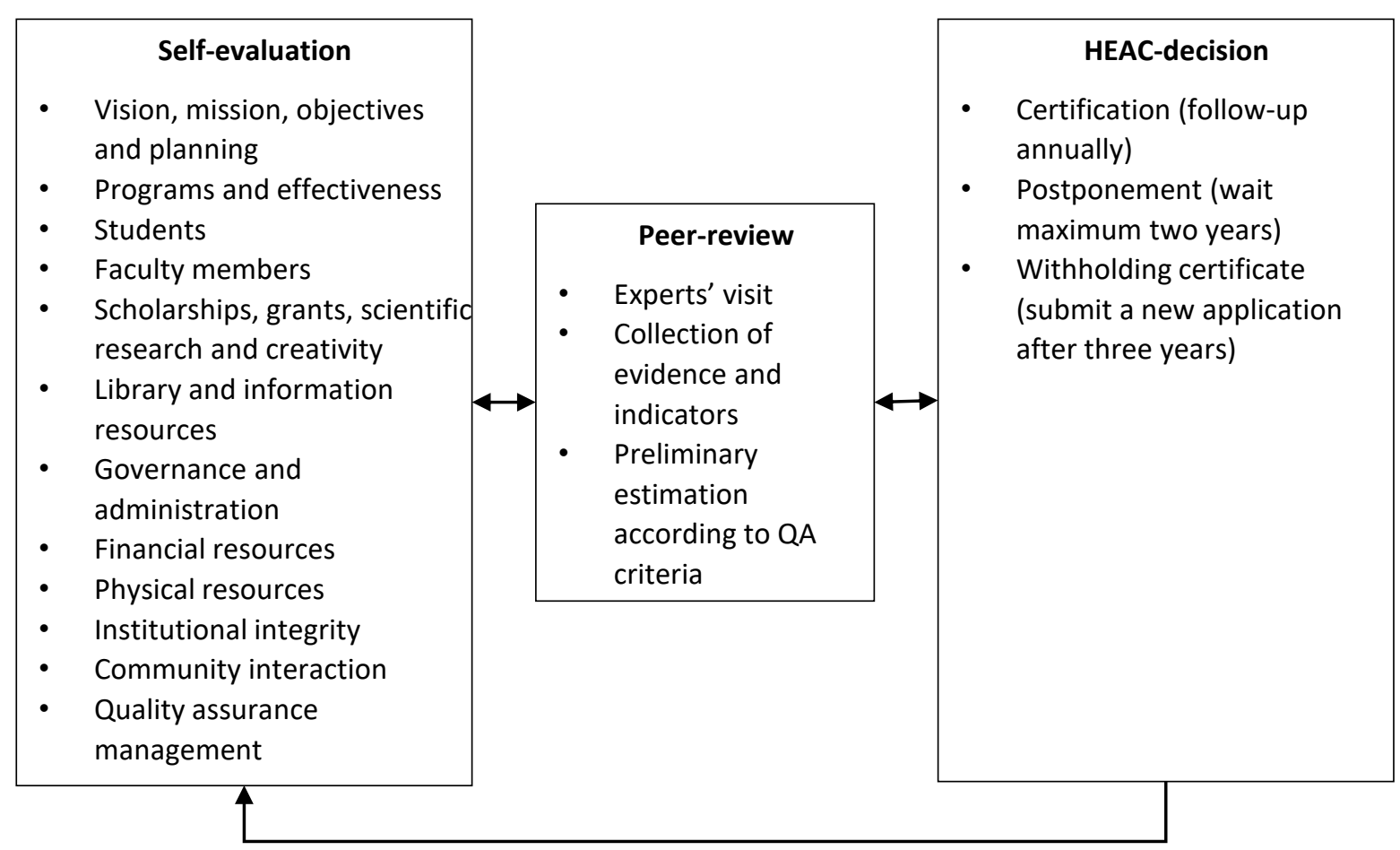

Figure 2. Quality assurance system framework

sion was to increase the standard of specializations and faculty members in Jordanian universities to internationally recognized standards, and its aims were to establish benchmarks for quality assurance system and accreditation in Jordanian universities; monitor and ensure that Jordanian universities are committed to quality assurance and accreditation system; and encourage the cooperation between Jordanian universities and international research centers and quality control commissions. HEAC has focused on three pillars, these are: 1) accreditation for universities, community colleges, and joint programs; 2) quality assurance procedure for universities and programs; 3) national testing center for assessments and testing services, and consultative services (MoHESR, 2018).

It is worth to notice that all private universities have followed the Accreditation Council criteria since they have been established, however, the Accreditation Council has less power on public universities as they still have the power to accredit their own programs and courses, and the Accreditation Council is restricted in licensing and recognizing courses and programs in private universities. In 2011, a committee was established for establishing the ranking system of the Jordanian universities, this system is based on six concepts: research outputs; faculty; students; facilities; finance; and university programs.

\subsection{Quality assurance system implementation: theoretical framework}

Quality assurance in Jordanian universities started to take place in 2007, when the board of accrediting the higher educational institutions established the criteria and indicators of quality assurance based on the Law No. 20 of 2007 (MoHESR, 2018). Quality assurance framework aims at the continuous improvement in the higher educational institutions, this process goes through three stages (see Figure 2): stage 1 - self-evaluation: information, verifications and indicators on each of the 12 criteria of the educational institutions of the Jordanian universities are provided in the self-evaluation report, stage 2 - peer-review: in this stage, a specialized external team visits the university to make sure that the data submitted in the self-evaluation report (information, verifications and indicators) are real, stage 3 - decision making, in this stage, the council reviews the report submitted by the external reviewers in order to make the final decision about issuing the quality assurance certificate. 
The process of quality control standards in Jordan includes a set of criteria and indicators laid down by the board of accrediting the higher educational institutions. The criteria are: the institution's vision, mission, objectives and planning; the educational programs and their effectiveness and efficiency; students and student support services; faculty members; scholarships; research, creativity and innovation; library and information sources, governance and administration; financial resources; physical resources; institutional integrity; community engagement; quality assurance management.

The research problem in this paper is that most Jordanian universities have established quality assurance offices, these offices started stage 1 of the quality control process in 2007, which is self-evaluation to collect data and information, verifications, documents and indicators on each of the 12 criteria to prepare the self-evaluation report. However, since 2007, two or three universities have submitted the self-evaluation report to the Higher Education Accreditation Council (HEAC). Up till now, one private university has achieved and obtained the quality assurance certificate from the Higher Education Accreditation Commission in Jordan in 2015, which is Petra University (HEAC, 2018). Petra University is regarded as the first university in Jordan that received this certificate.

\section{RESEARCH APPROACH AND DESIGN}

\subsection{Research approach}

Implementing quality assurance in the Jordanian universities may offer many benefits and promises, yet its adoption is faced by a number of challenges and obstacles that need to be identified in order to realize the promised benefits. Most of the Jordanian universities are stuck in stage 1: self-evaluation, our argument in this paper is that universities are stuck in this stage for many issues and challenges, previous studies have identified different obstacles and challenges in developed countries, such as quality innovations (Barnett, 2014; Lozano et al., 2013; Wals, 2014); awareness (Siemens et al., 2013; Hou, 2014; Laguador et al., 2014); change (Ceulemans et al., 2015; Kok \& McDonald, 2017); quality concept (Asif et al., 2013; Holt et al., 2014; Manatos et al., 2017) and other obstacles. The success of quality assurance process in Jordanian universities is subject to understanding, acceptance, awareness of quality assurance, Higher Education Accreditation Commission needs to work on limiting the power of these challenges, in order to realizing a comprehensive national strategy for the most important sector in Jordan. This area of research does not seem to have received enough attention so far, at least in Jordan, in order to help universities to move from stage 1 to stage 2 in implementing quality assurance system. For this reason, we have decided to research into practitioner's perceptions of quality assurance implementation within higher educational institutions.

In order to achieve the objectives of this research in exploring the issues and challenges to the implementation of quality assurance system in the Jordanian universities, the following research questions need to be answered by universities, and mainly quality assurance offices, Higher Education Accreditation Commission who are most involved in quality assurance processes.

What are the main issues and challenges in implementing quality assurance system in the Jordanian universities?

\subsection{Research method}

This research follows the quantitative approach (questionnaire) at this stage of work. The questionnaire was developed based on both previous literature and interviews with some experts with significant experience in quality assurance in higher education institutes in Jordan. A 5 -point Likert scale ranging from 1 as strongly disagree to 5 as strongly agree were used for the measurement in the questionnaire. Before the formal survey was distributed to the Jordanian universities, two pilot iterations were conducted; the first iteration involved two Ph.D. colleagues; based on their feedback, certain questions in the survey were modified with minor changes, which were made to improve the clarity and readability. The second iteration involved ten colleagues, there were minor changes, 


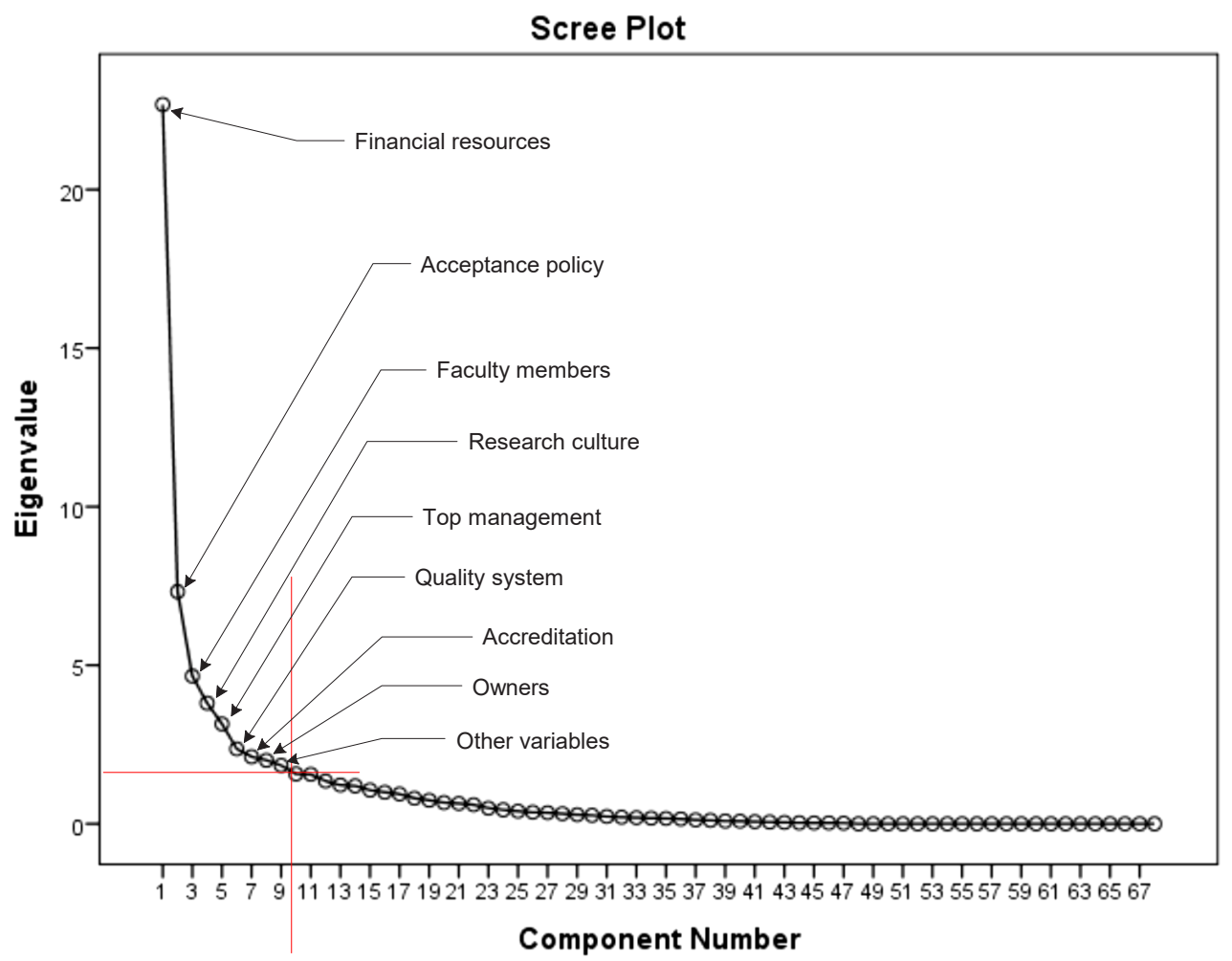

Figure 3. Eigenvalue of the nine factors extracted

giving us the confidence to issue the questionnaire. The questionnaire included fixed-choice questions about the main issues and challenges in implementing quality assurance system in the Jordanian universities. The questionnaire included 68 questions related to main issues and challenges of quality assurance system implementation. Data collection process for this work took place in June-September 2018.

The data from questionnaire were analyzed using the parametric statistical methods: descriptive analysis and factor analysis. As the questionnaire includes 68 questions, a factor analysis technique was used to identify possible categories for future work. Factor analysis was performed in the following steps: firstly, a matrix of correlation coefficients for all possible pairings of all variables was generated. Secondly, factors were then extracted from the matrix of correlation using principal factor analysis. Thirdly, the factors were rotated to maximize the relationships between the variables and the factors and to minimize association with other variables using Varimax Kaiser Normalization (Al-Yaseen et al., 2011).

\section{RESULTS AND DISCUSSION}

The questionnaire was sent by email to people directly involved in implementing quality assurance system in all public and private universities (150 questionnaires, 5 questionnaires were distributed in each university). Of the 150 questionnaires addressed, 1 was returned empty, 2 were returned uncompleted, 147 completed questionnaires were returned with a total response rate of $98 \%$, which is considered to be high and above expectation.

Based on factor analysis of the questionnaire, nine factors have an Eigenvalue ( $>1)$ as shown in Figure 3, which we termed: "Financial resources" is highly correlated with ten variables, second factor "Acceptance policy" is highly correlated with seven variables, third factor "Faculty members" is highly correlated with seven variables, fourth factor "Research culture" is highly correlated with seven variables, fifth factor "Top management" is highly correlated with seven variables, sixth factor "Quality system" is highly correlated with twelve variables, seventh factor "Accreditation" is highly correlated with three variables, eight fac- 
tor "Owners" is highly correlated with six variables and the ninth factor which we termed "Other variables" is highly correlated with nine variables, for more details (see Appendices A, B).

The research objective was to explore the issues and challenges when implementing quality assurance system in the Jordanian universities; progress in the field of quality assurance in Jordanian universities is slow because of the nine challenges/ factors (Figure 3).

For Jordanian universities in particular, in order to move forward in implementing quality assurance systems, it is recommended that universities should increase the required financial resources and spend enough on the educational process; change and improve the policy of students acceptance in universities; concentrate on the variables related to faculty members factor; pay more attention to scientific research for faculty members and postgraduate students; enhance the integration between top management and managerial and academic staff; quality assurance system applied in Jordanian universities needs to be reviewed; accreditation council in Jordan need to work with the universities in general and private universities in particular; owners of the private universities need to work with the top management and academic staff for alignment purposes to move one step forward in the quality assurance system.

\section{CONCLUSION}

High level of supervision and restrictions has to be decreased from both Ministry of Scientific Research and Higher Education and Accreditation Council in Jordan in order to increase the collaboration between decision-makers and higher educational institutions will lead to education quality improvement and universities innovation.

There is a need in Ministry of Scientific Research and Higher Education in Jordan for a comprehensive revision of quality assurance system and accreditation process, furthermore, to establish a reform initiative in order to tackle the numerous challenges facing higher educational institutions in Jordan.

The research findings hoped to be useful for both universities and policy makers in the government in order to realize the full benefits of implementing quality assurance system. Hence, this and other research on implementing quality assurance in higher educational institutions might be of assistance. A comparable evaluation of the Jordanian educational perspectives in association with other Middle East countries can be conducted in the future work.

\section{REFERENCES}

1. Al-Adwan, A. S., Al-Madadha, A., \& Zvirzdinaite, Z. (2018). Modeling Students' Readiness to Adopt Mobile Learning in Higher Education: An Empirical Study. The International Review of Research in Open and Distributed Learning, 19(1). https://doi. org/10.19173/irrodl.v19i1.3256

2. Al-Hassan, O. M. (2018). Developments of early childhood education in Jordan. Early Years, 38(4), 351-362. https://doi.org/10. 1080/09575146.2018.1512562

3. Al-Jaghoub, S., Al-Yaseen, H., \& Al-Hourani, M. (2010). Evaluation of awareness and acceptability of using e-government services in developing countries: The case of Jordan. The Electronic Journal Information Systems Evaluation, 13(1), 1-8. Retrieved from file:///C:/Users/Inna/Desktop/\% D0\%97\%D0\%B0\%D0\%B3\%D1\% 80\%D1\%83\%D0\%B7\%D0\%BA\% D0\%B8/ejise-volume13-issue1article651.pdf

4. Al-Soud, A., Al-Yaseen, H., \& Al-Jaghoub, S. H. (2014). Jordan's e-Government at the crossroads. Transforming Government: People, Process and Policy, 8(4), 597-619. https://doi.org/10.1108/TG-102013-0043
5. Altbach, P. (2015). Reforming Higher Education in the Middle East and Elsewhere. International Higher Education, 64. Retrieved from https://ejournals.bc.edu/ ojs/index.php/ihe/article/ view/8566/7699

6. Al-Widyan, M. I., \& Qdais, H. A. (2018). Quality Assurance at Jordan University of Science and Technology (JUST): Integrating Administrative Quality and Academic Accreditation. In The Future of Higher Education in the Middle East and Africa (pp. 2131). Springer, Cham. 
7. Al-Yaseen, H. M. (2012).

Challenges of Implementing Health Care Information Systems in Developing Countries: Using a Mixed Method Research. Journal of Emerging Trends in Computing and Information Sciences, 3(11), 1521-1525. Retrieved from http:// citeseerx.ist.psu.edu/viewdoc/down load?doi=10.1.1.480.7435\&rep=rep $1 \&$ type $=\mathrm{pdf}$

8. Al-Yaseen, H., \& Al-Jaghoub, S. (2012). Success and failure of e-learning projects: alignment of vision and reality, change and culture. Journal of Emerging Trends in Computing and Information Sciences, 3(2), 277-284. Retrieved from https://www.ammanu.edu.jo/ English/pdf/StaffResearch/IT/749/ Success\%20and\%20Failure\%20 of $\% 20$-Learning $\% 20$ Projects $\% 20$ Alignment $\% 20$ of $\% 20$ Vision $\% 20$ and\%20Reality,\%20Change\%20 and\%20Culture.pdf

9. Al-Yaseen, H., Al-Jaghoub, S., \& Al-Salhi, N. (2011). Issues and Challenges in Implementing E-Learning Projects in Higher Education: The Case of Jordan. Proceedings of the 10th European Conference on E-Learning (ECEL). UK.

10. Al-Yaseen, H., Al-Soud, A. R., \& Al-Jaghoub, S. (2015). Assessing Jordan's e-government maturity level: Citizen's perspective on awareness, acceptability and usage of e-government services. In Public Affairs and Administration: Concepts, Methodologies, Tools, and Applications (pp. 1596-1613). IGI Global.

11. Al-Yaseen, H., Al-Soud, A., \& Al-Jaghoub, S. (2013). Assessing Jordan's e-government maturity level: Citizen's perspective on awareness, acceptability and usage of e-government services. International Journal of Electronic Government Research (IJEGR), 9(4). https://doi.org/10.4018/978-14666-8358-7.ch081

12. Asif, M., Awan, M. U., Khan, M. K., \& Ahmad, N. (2013). A model for total quality management in higher education. Quality \& Quantity, 47(4), 1883-1904. Retrieved from https://link.springer.com/article/10.1007/s11135-011-9632-9
13. Barnett, R. (2014). Conditions of Flexibility: Securing a More Responsive Higher Education System. Higher Education Academy.

14. Blanco-Ramírez, G., \& Berger, J. B. (2014). Rankings, accreditation, and the international quest for quality: Organizing an approach to value in higher education. Quality Assurance in Education, 22(1), 88-104. https://doi.org/10.1108/ QAE-07-2013-0031

15. Bongaarts, J., Mensch, B. S., \& Blanc, A. K. (2017). Trends in the age at reproductive transitions in the developing world: the role of education. Population studies, 71(2), 139-154. https://doi.org/10. 1080/00324728.2017.1291986

16. Ceulemans, K., Lozano, R., \& Alonso-Almeida, M. D. M. (2015). Sustainability reporting in higher education: Interconnecting the reporting process and organisational change management for sustainability. Sustainability, 7(7), 8881-8903. https://doi.org/10.3390/su7078881

17. Damian, R., Grifoll, J., \& Rigbers, A. (2015). On the role of impact evaluation of quality assurance from the strategic perspective of quality assurance agencies in the European higher education area. Quality in Higher Education, 21(3), 251-269.

18. Dill, D. D. (2014). Ensuring academic standards in US higher education. Change: The magazine of higher learning, 46(3), 53-59. https://doi.org/10.1080/00091383. 2014.910043

19. Dotong, C. I., \& Laguador, J. M. (2015). Philippine Quality Assurance Mechanisms in Higher Education towards Internationalization. Studies in Social Sciences and Humanities, 3(3), 156-167. Retrieved from http://research.lpubatangas.edu. $\mathrm{ph} / \mathrm{wp}$-content/uploads/2015/12/ SSSH-Philippine-Quality-Assurance-Mechanisms-in-HigherEducation.pdf

20. Dunn, W. B., Broadhurst, D. I., Edison, A., Guillou, C., Viant, M. R., Bearden, D. W., \& Beger, R. D. (2017). Quality assurance and quality control processes: summary of a metabolomics community questionnaire. Metabolomics, 13(5), 50. https:// doi.org/10.1007/s11306-0171188-9

21. Ebisine, S. S. (2014). Academic quality Assurance in the colleges of education: Challenges and ways forward for future development. International Letters of Social and Humanistic Sciences, 13, 1-9. Retrieved from https://www. scipress.com/ILSHS.13.1

22. Espinoza, Ó., \& Eduardo González, L. (2013). Accreditation in higher education in Chile: results and consequences. Quality Assurance in Education, 21(1), 20-38. https://doi. org/10.1108/09684881311293043

23. Gaston, P. L. (2013). Higher education accreditation: How it's changing, why it must. Stylus Publishing, LLC.

24. HEAC (2018) Higher Education Accreditation Council. Retrieved from www.heac.org.jo/en (accessed on January, 2018).

25. Holt, D., Palmer, S., Gosper, M., Sankey, M., \& Allan, G. (2014). Framing and enhancing distributed leadership in the quality management of online learning environments in higher education. Distance Education, 35(3), 382-399. https://dx.doi.org/ 10.1080/01587919.2015.955261

26. Hou, A. Y. C. (2014). Quality in cross-border higher education and challenges for the internationalization of national quality assurance agencies in the Asia-Pacific region: The Taiwanese experience. Studies in Higher Education, 39(1), 135-152. http:// dx.doi.org/10.1080/03075079.201 1.646258

27. Hou, Y. C., Morse, R., Ince, M., Chen, H. J., Chiang, C. L., \& Chan, Y. (2015). Is the Asian quality assurance system for higher education going glonacal? Assessing the impact of three types of program accreditation on Taiwanese universities. Studies in Higher education, 40(1), 83-105. https://doi.org/10.1080/03075079. 2013.818638 
28. Houston, D., \& Paewai, S. (2013). Knowledge, power and meanings shaping quality assurance in higher education: a systemic critique. Quality in Higher Education, 19(3), 261-282. https:// doi.org/10.1080/13538322.2013. 849786

29. Kanaan, T. H. (2018). The Politica Economy of Higher Education in Jordan: Cost-Sharing Revisited. In Universities in Arab Countries: An Urgent Need for Change (pp. 249286). Springer, Cham.

30. Khouja, M., Rodriguez, I.

B., Halima, Y. B., \& Moalla, S. (2018). IT Governance in Higher Education Institutions: A Systematic Literature Review. International Journal of Human Capital and Information Technology Professionals (IJHCITP), 9(2), 52-67. http:// dx.doi.org/10.4018/IJHCITP.2018040104

31. Kok, S. K., \& McDonald, C. (2017). Underpinning excellence in higher education-an investigation into the leadership, governance and management behaviours of high-performing academic departments. Studies in Higher Education, 42(2), 210-231. https://doi.org/10.1080/03075079. 2015.1036849

32. Kwiek, M. (2014). Structural changes in the Polish higher education system (1990-2010): a synthetic view. European Journal of Higher Education, 4(3), 266280. Retrieved from https://eric. ed.gov/?id=EJ1089081

33. Laguador, J. M., Villas, C. D., \& Delgado, R. M. (2014). The Journey of Lyceum of The Philippines University-Batangas Towards Quality Assurance and Internationalization of Education. Asian Journal of Educational Research, 2(2), 45-49 Retrieved from http:// research.lpubatangas.edu.ph/ wp-content/uploads/2014/12/ AJER-THE-JOURNEY-OF-LYCEUM-OF-THE-PHILIPPINESUNIVERSITY-BATANGASTOWARDS-QUALITY-ASSURANCE-AND-INTERNATIONALIZATION-OF-EDUCATION.pdf
34. Lipset, S. M. (2018). Values, education, and entrepreneurship. In Promise of Development (pp. 39-75). Routledge.

35. Lozano, R., Lukman, R., Lozano, F. J., Huisingh, D., \& Lambrechts, W. (2013). Declarations for sustainability in higher education becoming better leaders, through addressing the university system. Journal of Cleaner Production, 48, 10-19. https://doi.org/10.1016/j. jclepro.2011.10.006

36. Manatos, M. J., Sarrico, C. S., \& Rosa, M. J. (2017). The integration of quality management in higher education institutions: a systematic literature review. Total Quality Management \& Business Excellence, 28(1-2), 159-175. https://doi.org/1 $0.1080 / 14783363.2015 .1050180$

37. $\mathrm{MoE}$ (2018) Ministry of Education Retrieved from www.moe.gov.jo/ en/ (accessed on February 2018).

38. MoHESR (2018). Ministry of Higher Education and Scientific Research. Retrieved from www. mohe.gov.jo/en/pages/default.aspx (accessed on March 2018).

39. Moreira, F., Ferreira, M. J., Santos, C. P., \& Durão, N. (2017). Evolution and use of mobile devices in higher education: A case study in Portuguese Higher Education Institutions between 2009/2010 and 2014/2015. Telematics and Informatics, 34(6), 838-852. https://doi.org/10.1016/j. tele.2016.08.010

40. Navaneedhan, C. G., \& Kamalanabhan, T. J. (2015). Efficacy of Innovative Technological Approach Ensuring Quality Assurance in Teaching Learning Process in Open and Distance Learning. Open Access Library Journal, 2(12), 1. http:// dx.doi.org/10.4236/oalib.1102166

41. Siemens, G., Dawson, S., \& Lynch, G. (2013). Improving the quality and productivity of the higher education sector. Policy and Strategy for Systems-Level Deployment of Learning Analytics. Canberra, Australia: Society for Learning Analytics Research for the Australian Office for Learning and Teaching.
42. Stimac, H., \& Katic, S. (2015). Quality Assurance in Higher Education. Interdisciplinary Management Research, 11, 581591.

43. Wals, A. E. (2014). Sustainability in higher education in the context of the UN DESD: a review of learning and institutionalization processes. Journal of Cleaner Production, 62, 8-15. https://doi. org/10.1016/j.jclepro.2013.06.007 


\begin{tabular}{|c|c|c|c|c|c|c|c|c|c|}
\hline \multicolumn{10}{|c|}{ Component Matrix } \\
\hline \multirow[b]{2}{*}{ Code } & \multicolumn{9}{|c|}{ Factors } \\
\hline & $\begin{array}{l}\text { Financial } \\
\text { resources }\end{array}$ & $\begin{array}{c}\text { Acceptance } \\
\text { policy }\end{array}$ & $\begin{array}{c}\text { Faculty } \\
\text { members }\end{array}$ & $\begin{array}{c}\text { Research } \\
\text { culture }\end{array}$ & $\begin{array}{c}\text { Top } \\
\text { management }\end{array}$ & $\begin{array}{l}\text { Quality } \\
\text { system }\end{array}$ & Accreditation & Owners & $\begin{array}{c}\text { Other } \\
\text { variables }\end{array}$ \\
\hline P1Q1 & .533 & .351 & -.091 & -.533 & -.146 & -.038 & .022 & -.111 & .225 \\
\hline P1Q2 & .595 & .381 & .134 & -.517 & -.023 & .314 & -.052 & .074 & .036 \\
\hline P1Q3 & .532 & .290 & -.099 & -.492 & -.159 & .155 & .018 & .073 & .225 \\
\hline P1Q4 & .548 & .351 & -.049 & -.539 & -.073 & -.026 & .004 & .230 & -.120 \\
\hline P1Q5 & .661 & .358 & -.014 & -.341 & -.160 & .053 & -.166 & .300 & .015 \\
\hline P1Q6 & .615 & .199 & -.034 & -.387 & -.015 & .296 & .008 & .290 & -.002 \\
\hline P1Q7 & .649 & .263 & -.090 & -.463 & .040 & .252 & -.042 & .142 & .066 \\
\hline P1Q8 & .596 & .247 & -.147 & .054 & .228 & .176 & -.141 & -.064 & .153 \\
\hline P1Q9 & .684 & .248 & -.065 & -.139 & .347 & -.070 & -.046 & -.219 & -.019 \\
\hline P1Q10 & .683 & .151 & -.153 & -.020 & .402 & .013 & -.172 & .137 & -.158 \\
\hline P2Q1 & .243 & .538 & -.129 & -.257 & -.158 & -.041 & -.333 & -.281 & -.011 \\
\hline $\mathrm{P} 2 \mathrm{Q} 2$ & .376 & .518 & .017 & -.207 & -.168 & -.383 & -.006 & -.180 & -.316 \\
\hline P2Q3 & .410 & .533 & -.112 & -.030 & -.086 & -.241 & .292 & .046 & -.289 \\
\hline P2Q5 & .187 & .552 & -409 & -.174 & .014 & -.118 & -.062 & -.230 & .041 \\
\hline P2Q6 & .487 & .546 & -.254 & -.234 & .134 & -.100 & -.066 & -.086 & -.030 \\
\hline P2Q7 & .519 & .538 & -.137 & -.087 & .186 & -.162 & .024 & -.150 & -.086 \\
\hline $\mathrm{P} 2 \mathrm{Q} 8$ & .550 & .551 & -.109 & .047 & -.006 & -.074 & -.045 & -.202 & -.008 \\
\hline P3Q2 & .412 & -.268 & .570 & .382 & -.007 & -.329 & -.023 & .119 & .179 \\
\hline P3Q3 & .383 & -.286 & .508 & .407 & .148 & -.356 & -.085 & .160 & .105 \\
\hline P3Q4 & .504 & -301 & .510 & .312 & .170 & -.220 & .047 & .009 & .147 \\
\hline P3Q5 & .207 & -.194 & .502 & .097 & -.132 & .388 & .277 & -.089 & .073 \\
\hline P3Q6 & -.037 & -.215 & .649 & .178 & .241 & .368 & .205 & -.016 & .345 \\
\hline P3Q7 & -.110 & -.115 & .572 & .104 & .423 & .409 & .245 & .068 & .193 \\
\hline P3Q8 & -.006 & -.112 & .572 & .218 & .253 & .427 & .282 & .047 & .052 \\
\hline P4Q1 & -.054 & .212 & .323 & .567 & -.315 & .083 & -.197 & -.215 & -.060 \\
\hline P4Q2 & .254 & .406 & .327 & .520 & -.237 & .038 & .097 & -.083 & -.085 \\
\hline P4Q3 & .265 & .162 & -.001 & .529 & -.153 & .233 & .090 & .073 & -.391 \\
\hline P4Q4 & .117 & .246 & .056 & .679 & -.127 & .099 & .054 & -.126 & -.328 \\
\hline P4Q6 & .209 & .131 & .119 & .565 & -.429 & .125 & -.125 & -.093 & -.192 \\
\hline P4Q8 & .130 & .100 & .213 & .714 & -.206 & .088 & -.115 & .057 & .065 \\
\hline P4Q9 & .158 & .049 & .416 & .636 & -.120 & .058 & .223 & -.318 & -.038 \\
\hline P5Q1 & -.411 & .053 & -.045 & -.081 & .788 & .038 & -.067 & -.010 & .032 \\
\hline P5Q2 & -.292 & .218 & -.112 & .000 & .838 & -.051 & .053 & -.054 & .082 \\
\hline P5Q3 & -.339 & .138 & -.062 & -.131 & .834 & -.127 & .063 & -.031 & -.006 \\
\hline P5Q4 & -.296 & .202 & .036 & .016 & .824 & -.079 & .163 & -.181 & .052 \\
\hline P5Q5 & -.391 & .198 & -.178 & -.017 & .797 & .064 & .063 & -.038 & -.039 \\
\hline P5Q6 & -.112 & .114 & .072 & .031 & .798 & .040 & -.144 & .028 & -.172 \\
\hline P5Q7 & -.153 & .247 & .094 & -.059 & .725 & -.093 & .246 & .136 & -.143 \\
\hline P6Q1 & -.410 & .241 & -.020 & -.185 & -.118 & .668 & -.151 & -.160 & .247 \\
\hline P6Q2 & -.306 & .252 & -.078 & -.027 & -.202 & .767 & -.086 & -.121 & .257 \\
\hline P6Q3 & -.334 & .364 & -.068 & -.055 & -.180 & .750 & -.105 & -.049 & .166 \\
\hline P6Q4 & -.297 & .325 & -.142 & -.073 & -.108 & .760 & -.074 & -.013 & .153 \\
\hline P6Q5 & -.361 & .241 & -.007 & .009 & -.092 & .794 & -.128 & -.088 & -.001 \\
\hline P6Q6 & -.241 & .099 & .166 & -.056 & .030 & .722 & .153 & .113 & .162 \\
\hline P6Q7 & -.281 & .131 & .217 & -.036 & .026 & .710 & .127 & .086 & .105 \\
\hline P6Q8 & -.175 & .073 & .105 & .088 & -.237 & .650 & .220 & .119 & -.089 \\
\hline P6Q9 & -.325 & -.063 & .093 & -.027 & .014 & .702 & .079 & .083 & .110 \\
\hline P6Q10 & -.018 & .094 & .078 & .065 & -.163 & .726 & .089 & .082 & .205 \\
\hline
\end{tabular}


Component Matrix

\begin{tabular}{|c|c|c|c|c|c|c|c|c|c|}
\hline \multirow{2}{*}{ Code } & \multicolumn{9}{|c|}{ Factors } \\
\hline & $\begin{array}{l}\text { Financial } \\
\text { resources }\end{array}$ & $\begin{array}{l}\text { Acceptance } \\
\text { policy }\end{array}$ & $\begin{array}{l}\text { Faculty } \\
\text { members }\end{array}$ & $\begin{array}{c}\text { Research } \\
\text { culture }\end{array}$ & $\begin{array}{c}\text { Top } \\
\text { management }\end{array}$ & $\begin{array}{l}\text { Quality } \\
\text { system }\end{array}$ & Accreditation & Owners & $\begin{array}{c}\text { Other } \\
\text { variables }\end{array}$ \\
\hline P6Q11 & -.136 & -.001 & .165 & .123 & -.233 & .616 & .222 & .427 & -.226 \\
\hline P6Q12 & -.214 & .057 & -.103 & .092 & -.073 & .532 & -.088 & .427 & -.140 \\
\hline P7Q1 & .270 & .375 & -.071 & .127 & -.221 & -.230 & .610 & -.194 & -.148 \\
\hline P7Q2 & .222 & .279 & .010 & .070 & -.121 & -.121 & .646 & -.321 & .039 \\
\hline P7Q5 & .029 & .382 & -.168 & -.001 & .012 & .410 & .523 & -.245 & -.267 \\
\hline P8Q1 & -.493 & .359 & -.079 & .072 & -.023 & .091 & .083 & .643 & .145 \\
\hline P8Q2 & -.373 & .398 & -.120 & -.039 & -.020 & .054 & .164 & .721 & .130 \\
\hline P8Q3 & -.485 & .400 & -.002 & .003 & .042 & .106 & -.016 & .680 & .114 \\
\hline P8Q4 & -.340 & .465 & -.033 & -.023 & -.007 & .061 & .155 & .696 & .167 \\
\hline P8Q5 & -.466 & .463 & -.005 & -.041 & -.058 & .025 & .170 & .518 & .122 \\
\hline P8Q6 & -.298 & .397 & .107 & -.046 & -.211 & .145 & .042 & .630 & .204 \\
\hline P2Q4 & .415 & -.122 & .127 & -.049 & -.128 & .342 & .068 & -.096 & .453 \\
\hline P3Q1 & .277 & -.116 & -.093 & .368 & .221 & .333 & -.167 & .203 & .494 \\
\hline P4Q5 & .480 & .122 & .421 & -.037 & -.034 & .096 & -.253 & -.007 & .381 \\
\hline P4Q7 & .321 & .118 & .352 & -.033 & -.249 & .355 & .071 & -.319 & .380 \\
\hline P7Q3 & -.170 & .244 & -.168 & -.136 & .344 & -.065 & -.130 & -.230 & .406 \\
\hline P7Q4 & -.193 & .143 & -.007 & -.066 & .265 & -.255 & .059 & .000 & .425 \\
\hline P7Q6 & -.229 & .166 & .109 & -.072 & .461 & -.066 & -.278 & .307 & .461 \\
\hline P9Q1 & .252 & -.010 & .142 & .391 & -.047 & -.345 & .231 & -.266 & .460 \\
\hline P9Q2 & .111 & .286 & .211 & -.053 & .018 & .049 & -.618 & .158 & .334 \\
\hline \multicolumn{10}{|c|}{ Extraction method: principal component analysis. } \\
\hline & & & & 9 compc & ents extracted. & & & & \\
\hline
\end{tabular}


APPENDIX B

\begin{tabular}{|c|c|c|c|}
\hline Code & Variable & Code & Variable \\
\hline P1Q1 & Spending infrastructure is limited & P5Q1 & University do not have strategic planning \\
\hline P1Q2 & Spending on research projects is limited & P5Q2 & Top management understanding of $\mathrm{QA}$ is not clear \\
\hline P1Q3 & Spending on attending conferences is limited & P5Q3 & $\begin{array}{l}\text { Alignment between top management and QA staff is } \\
\text { limited }\end{array}$ \\
\hline P1Q4 & Spending on scholarship is limited & P5Q4 & QA culture for top management is unclear \\
\hline P1Q5 & Spending on reputable scholars is not enough & P5Q5 & Commitment of top management to QA is limited \\
\hline P1Q6 & Spending on academic skills is limited & P5Q6 & Top management procedures will limit QA system \\
\hline P1Q7 & Spending on managerial skills is limited & P5Q7 & QA system will not improve top management quality \\
\hline P1Q8 & Student acceptance policy is neglected & P6Q1 & Lack of clear vision on QA system \\
\hline P1Q9 & Student academic level is not high & P6Q2 & Lack of clear mission of QA system \\
\hline P1Q10 & $\begin{array}{l}\text { Ignoring student academic level because of } \\
\text { competition }\end{array}$ & P6Q3 & Lack of clear objectives of QA system \\
\hline P2Q1 & Most students accepted in public universities & P6Q4 & Lack of clear strategic planning \\
\hline $\mathrm{P} 2 \mathrm{Q} 2$ & Students in public univ. will affect quality & P6Q5 & Lack of understanding of QA system \\
\hline P2Q3 & Students in public Univ. will affect outcomes & P6Q6 & Lack of understanding of QA system from academic staff \\
\hline $\mathrm{P} 2 \mathrm{Q} 4$ & Students in public Univ. support QA system & P6Q7 & $\begin{array}{l}\text { Lack of understanding of QA system from managerial } \\
\text { staff }\end{array}$ \\
\hline P2Q5 & Students with low average go to private Univ. & P6Q8 & Resources for QA system is limited \\
\hline P2Q6 & Students with low average affect quality & P6Q9 & Lack of experts in QA system \\
\hline $\mathrm{P} 2 \mathrm{Q} 7$ & Students with low average affect outcomes & P6Q10 & Lack of integrated QA system \\
\hline P2Q8 & $\begin{array}{l}\text { Students with low average will not support } \\
\text { QA system }\end{array}$ & P6Q11 & QA system is filing files and paper work \\
\hline P3Q1 & Teachers to students ratio is high & P6Q12 & QA system will not improve quality of universities \\
\hline P3Q2 & The high ratio affect quality & P7Q1 & Accreditation council has a strategic plan for QA system \\
\hline P3Q3 & The high ratio affect outcomes & P7Q2 & Accreditation council has clear vision and mission \\
\hline P3Q4 & The high ratio affect negatively QA system & P7Q3 & Accreditation council lack integrated QA system \\
\hline P3Q5 & It is difficult to acquire reputable scholars & P7Q4 & Accreditation council staff lack skills in QA \\
\hline P3Q6 & Teachers skills in QA system is limited & P7Q5 & Accreditation council have skilled staff \\
\hline P3Q7 & Teachers understanding of QA is limited & P7Q6 & QA evaluation process is not clear \\
\hline P3Q8 & Teachers commitments of QA is not enough & P8Q1 & Owners have clear vision about QA system \\
\hline P4Q1 & $\begin{array}{l}\text { Scientific research environment is } \\
\text { discouraged }\end{array}$ & P8Q2 & Owners have clear mission about QA system \\
\hline P4Q2 & Importance of scientific research is not clear & P8Q3 & Owners have clear objectives about QA system \\
\hline P4Q3 & Spending on scientific research is not enough & P8Q4 & Owners have clear strategic planning for QA system \\
\hline P4Q4 & Spending on attending conference is limited & P8Q5 & Owners have enough awareness about QA system \\
\hline P4Q5 & Scientific research quality is moderate & P8Q6 & Owners believe QA system is important \\
\hline P4Q6 & Quantity of scientific projects is low & P9Q1 & QA system needs to change the culture \\
\hline P4Q7 & Teachers understanding of research is limited & P9Q2 & QA system start by changing student's culture at schools \\
\hline P4Q8 & $\begin{array}{l}\text { Top management understanding of research } \\
\text { is limited }\end{array}$ & & \\
\hline P4Q9 & QA affect negatively scientific research & & \\
\hline
\end{tabular}

